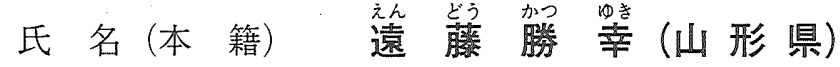

学位の種類医学 博士

学 位記 番号博 乙 第 460 号

学位授与年月日 昭和 63 年 6 月 30 日

学位授与の要件＼cjkstart学位規則第 5 条第 2 項該当

審査研究科医学研究科

学位論文題目 Two murine monoclonal antibodies against human lung cancerassociated antigens

(ヒト肺癌関連抗原に対する 2 種類のマウス・モノクロナール抗体)

$\begin{array}{llllllll}\text { 主 } & \text { 查 } & \text { 筑波大学教授 } & \text { 医学博士 } & \text { 東 } & & \text { 惪 } & \text { 彦 } \\ \text { 副 } & \text { 查 } & \text { 筑波大学教授 } & \text { 医学博士 } & \text { 稲 } & \text { 田 } & \text { 哲 } & \text { 雄 } \\ \text { 副 } & \text { 查 } & \text { 筑波大学教授 } & \text { 医学博士 } & \text { 大 } & \text { 貫 } & & \text { 稔 } \\ \text { 副 } & \text { 查 } & \text { 筑波大学教授 } & \text { 医学博士 } & \text { 中 } & \text { 村 } & \text { 恭 } & \text { 一 } \\ \text { 副 } & \text { 查 } & \text { 筑波大学教授 } & \text { 医学博士 } & \text { 長 谷川 } & \text { 鎮 } & \text { 雄 }\end{array}$

論文の要旨

a. 目 的

癌細胞の抗原決定基を認識するモノクロナール抗体が癌の研究や臨床に多大の利益をもたらすこ とは論をまたない。これまで肺癌に対するモノクロナール抗体は数多く作製されているが，小細胞 癌変異株を抗原とする研究は 1 例に過ぎないので, これに属すると考えられる細胞（肺小細胞癌患 者の鎖骨上窩リンパ腺転移巣から得たTKB-2）を用いてマウスモノクロナール抗体を作製し，各種 腫瘍株細胞，腫瘍組織，正常細胞における認識抗原の分布を検索するとともに，その生化学的性状 を明らかにし，臨床応用の方途を探求した。

b. 実験結果

1.モノクロナール抗体の作製

TKB- 2 細胞で免疫した BALB / c マウスの脾細胞と, マウスミエローマ細胞（P3X63Ag8U 1$)$ とをポリエチレングリコール4000を用いて融合させ，ハイブリドーマの培養上清を ELISA 法によっ て検査し，TKB-2 細胞と反応し B リンパ芽球様細胞や線維芽細胞とは反応しないものを選別した。 クローニングの結果，安定した抗体産生を示す13クローンを得，そのうちの2つ（MAb 8 とAb 15）をマウスに注射し，その腹水から硫安塩析とDEAE-セファセル・クロマトグラフィーによって 抗体を分離精製した。 


\section{2. 免疫組織化学的検索}

上記のようにしてえられた 2 種のモノクロナール抗体と, 24 種類の腫瘍株細胞との免疫学的反応 を ELISA 法で調べた。各組織型の肺癌株細胞の他に,いくつかの他臓器腫瘍の株細胞とも反応した。 肺癌細胞で強陽性反応を呈したのは，免疫原として用いた TKB-2 を除いてすべて大細胞癌であった。

ヒト癌組織の凍結切片について，これら抗体と結合する抗原の存否をアビジン・ビオチン複合体 酵素免疫法によって検索した。65例の肺癌において，MAb 8 は扁平上皮癌，腺癌，小細胞癌，大細 胞癌のそれぞれ $82 ， 82 ， 19 ， 87 \%$ と反応し，全体では68\%の陽性率であった。一方 MAb15は，上記 各型とそれぞれ76，71，44，100\%に反応し，肺癌全体では72\%に陽性であった。両抗体とも小細胞 癌との反応率が低い。MAb 8 は癌細胞の膜および細胞質の両者に, MAb15はもっぱら細胞膜に結合 した。また両抗体とも, 肺癌以外の腫瘍組織や正常組織との反応は限られた例のみに認められた。

3. 抗原の生化学性状

${ }^{3} \mathrm{H}$ グルコサミンで標識した TKB- 2 細胞を可溶化した後, MAb 8 を反応させて生じる免疫沈降物 をSDS・ポリアクリルアミドゲル電気泳動で分析したところ，48KD に明瞭な抗原バンドを検出した。 一方 TKB- 2 細胞の可溶化標品を電気泳動した後, MAb15と反応するバンドをイムノブロット法で 検索したところ，82KD と45KD に陽性のバンドが検出された，これらの抗原性物質について，プロ テアーゼ，過ヨウ素酸，ノイラミニダーゼ，加熱処理の影響を検討した成績に基き，以下のように 推論された。

(1) MAb 8 は分子量 48,000 糖蛋白質の糖鎖部分を認識するが，シアル酸の関与はない。

(2) MAb15は分子量82,000と45,0000糖蛋白質のシアル酸に被われた蛋白部分を認識している。

\section{審查の要旨}

本研究においてえられた 2 種のモノクロナール抗体は，新しい肺癌関連抗原を認識するものであ り, 今後の肺癌臨床研究に扔いて有用な探索子になるものと考えられる。当面の課題として, 喀痰 内の癌細胞のスクリーニング, 患者血清中の抗原性蛋白質の早期検出, 癌の局在診断のためのイ メージングなどに関する研究が始っているとのことで，臨床応用への発展が期待される。

よって，著者は医学博士の学位を受けるに十分な資格を有するものと認める。 